\title{
Influence of storage on the chemical composition of Stylosanthes hays for equine feeding
}

\section{Influência da estocagem na composição química de fenos de estilosantes para alimentação equina}

\author{
Maria Lindomárcia Leonardo da $\operatorname{Costa}^{1 *}$; Adalgiza Souza Carneiro de Rezende ${ }^{2}$; \\ Ângela Maria Quintão Lana²; Juliano Martins Santiago ${ }^{3}$; \\ Eloísa de Oliveira Simões Saliba'; ${ }^{2}$ Vinícius Pimentel Silva ${ }^{4}$; Vany Perpétua Ferraz ${ }^{5}$; \\ Dalton Colares de Araújo Moreira ${ }^{6}$
}

\begin{abstract}
During dry seasons, equines are traditionally fed hay. However, if not prepared under favorable climatic conditions and if not properly stored, hay does not preserve its nutritional value. The aim of this research was to evaluate the chemical composition in Stylosanthes guianensis cv. Mineirão and Estilosantes Campo Grande hay varieties, used to feed equines over 225 days of storage. Treatments consisted of Stylosanthes guianensis cv. Mineirão and Estilosantes Campo Grande hay varieties, assessed at six moments of storage: $0,45,90,135,180$, and 225 days. The experiment followed a completely randomized split-plot design. In the comparison between varieties, differences $(\mathrm{P}<0.05)$ were found for dry matter, acid detergent insoluble nitrogen, neutral detergent fiber, and lignin. The storage period altered $(\mathrm{P}<0.05)$ the concentrations of dry matter, calcium, and crude protein in both hay varieties. The beta-carotene content in the leguminous plants did not decline $(\mathrm{P}>0.05)$ over the 225 days of storage. The storage period had little impact on the nutritional quality of the assessed hays. The Stylosanthes guianensis cv. Mineirão and, mainly, Estilosantes Campo Grande hay varieties have potential to be used in equine diet.
\end{abstract}

Key words: Beta-carotene. Chemical composition. Equus caballus.

\section{Resumo}

Durante a época seca, equinos são tradicionalmente alimentados com feno, entretanto, se não forem preparados em condições climáticas favoráveis e bem estocados, não preservam seu valor nutricional. $\mathrm{O}$ objetivo desse trabalho foi avaliar a influência do período de estocagem na composição bromatológica e concentração de betacaroteno dos fenos de Stylosanthes guianenses cv. Mineirão e Estilosantes Campo Grande durante 225 dias de armazenamento. Os tratamentos consistiram dos fenos de Stylosanthes guianenses cv. Mineirão e Estilosantes Campo Grande, avaliados em seis tempos de armazenamento:

\footnotetext{
${ }^{1}$ Prof $^{\mathrm{a}} \mathrm{Dr}^{\mathrm{a}}$, Departamento de Zootecnia, Universidade Federal da Paraíba, UFPB, Areia, PB, Brasil. E-mail: lindomarciacosta@ gmail.com

$2 \operatorname{Prof}^{\mathrm{as}} \operatorname{Dr}^{\mathrm{a}}$, Departamento de Zootecnia, Universidade Federal de Minas Gerais, UFMG, Belo Horizonte, MG, Brasil. E-mail: adalgizavetufmg@gmail.com; angelaquintao@gmail.com; saliba@vet.ufmg.br

${ }^{3}$ Prof. Dr., Universidade Federal Rural de Pernambuco, UFRPE, Serra Talhada, PE, Brasil. E-mail: jmartinssantiago@yahoo.com.br

${ }^{4}$ Prof. Dr., Universidade Federal Rural do Rio de Janeiro, UFRRJ, Seropédica, RJ, Brasil. E-mail: pimentelzootec@gmail.com

${ }^{5}$ Química, Dra ${ }^{\mathrm{a}}$, Departamento de Química, Universidade Federal de Minas Gerais, UFMG, Belo Horizonte, MG, Brasil. E-mail: vanyferraz@yahoo.com.br

${ }^{6}$ Médico Veterinário, Montes Claros, MG, Brasil. E-mail: dalton@catuni.com.br

* Author for correspondence
} 
$0,45,90,135,180$ e 225 dias. O delineamento experimental foi inteiramente ao acaso com arranjo em parcelas subdivididas. No comparativo entre as duas variedades, houve diferença $(p<0,05)$ no teor de matéria seca, fibra em detergente neutro, lignina e nitrogênio insolúvel em detergente ácido. O período de armazenamento alterou $(\mathrm{p}<0,05)$ o teor de matéria seca, cálcio e proteína bruta de ambas as variedades de feno. As concentrações de betacaroteno dos fenos de Estilosantes não declinaram $(\mathrm{P}>0,05)$ ao longo dos 225 dias de armazenamento. O período de armazenamento não afetou a qualidade nutricional dos fenos avaliados. As variedades dos fenos de Stylosanthes guianenses cv. Mineirão e, principalmente, Estilosantes Campo Grande têm potencial para serem usadas na dieta de equinos.

Palavras-chave: Betacaroteno. Composição bromatológica. Equus caballus.

\section{Introduction}

The Brazilian horse-raising system is based on extensive farming, with concentrate supplementation for the most demanding categories in the stalls and roughage storage for use in the dry season (CARVALHO; HADDAD, 1987).

Haymaking is one of the best forage conservation processes; according to Reis et al. (2001), as long as properly stored, hay maintains its nutritional value with little change over time and is able to meet the nutritional requirements of different animal categories and species. Those authors add that hay can be produced from a wide range of forage grasses and its production takes place in small or large scale, being harvested, stored, and fed to the animals manually or in a fully mechanized process.

Lucerne (Medicago sativa) hay is traditionally employed in equine diets; however, due to its high cost and limited production in most of the Brazilian territory, alternative legume sources that meet the nutritional needs of these animals at a low cost are needed. Jerba et al. (2006) considered the Stylosanthes genus the most important among the forage legumes found in tropical and subtropical regions. Nevertheless, few studies have assessed the nutritional quality of Stylosanthes cultivars for equine feeding (SILVA et al., 2009). It is crucial that this source be also rich in beta-carotene (pro-vitamin A), since horses are more sensitive to vitamin A deficiency than other species of zootechnical interest and that forages make up their main source of vitamin A. Furthermore, the hepatic reserve of this vitamin is limited in equines.
In face of the lack of research and the need for finding legumes adapted to the climate and humidity conditions in Brazil for use in equine diets during the dry season, the aim of this study was to assess the chemical composition and beta-carotene concentration of legumes Stylosanthes guianenses cv. Mineirão and Estilosantes Campo Grande over 225 days of storage.

\section{Materials and Methods}

The experiment was carried out at Stud Farm Catuni in the city of Montes Claros in the state of Minas Gerais, southeast Brazil.

Legumes Stylosanthes guianenses cv. Mineirão and Estilosantes Campo Grande were planted in a 1.5 ha plot in Catuni farm and harvested during the vegetative stage. Hay was made and immediately stored. During the storage period, the bales were kept over wood gratings in a $16 \mathrm{~m}^{2}$ masonry warehouse.

Over the trial period, the stored material was sampled in 45-day intervals. The samples of each bale were obtained from different spots on their surface and center. From each sample, part of the material was packed in several layers of black plastic, wrapped in aluminum foil, labeled, and frozen at $-20{ }^{\circ} \mathrm{C}$ for beta-carotene analysis. Another fraction of each sample, intended for the chemical analyses, was placed into a clear plastic bag, labeled, and stored at room temperature until they were ground in a Wiley mill with a $1 \mathrm{~mm}$ screen. 
The beta-carotene extractions and the chemical analyses of legumes were carried out at the Animal Nutrition Laboratory of the Veterinary School of the Federal University of Minas Gerais, and the quantification of beta-carotene concentrations was carried out in the Chromatography Laboratory of the Exact Sciences Institute of the same University.

The assessment of the hays' chemical composition consisted of the determination of dry matter, crude protein through the Kjeldahl method, and acid detergent insoluble nitrogen according to the Association of Official Analytical Chemistry AOAC (1995), while neutral detergent fiber and acid detergent fiber levels were obtained according to Van Soest et al. (1991). Mineral matter, calcium, phosphorus, lignin, and hemicellulose contents were obtained according to methodologies indicated by Silva and Queiroz (2002).

For beta-carotene extraction, the samples of both legume varieties were ground and then $1 \mathrm{~g}$ was weighed and placed into $50 \mathrm{~mL}$ flasks. Next, $15 \mathrm{~mL}$ of the extracting solution made up of $5 \mathrm{~mL}$ hexane, $3.5 \mathrm{~mL}$ acetone, $3 \mathrm{~mL}$ alcohol, and $3.5 \mathrm{~mL}$ toluene were pipetted. The solution was stirred for $1 \mathrm{~min}$ in a vortex, $500 \mu \mathrm{L}$ of ultrapure water were added and the solution was further stirred. $1 \mathrm{~mL} \mathrm{KOH} 40 \%$ was added and then the resulting material remained still for $16 \mathrm{~h}$ in a dark environment. After this period, 15 $\mathrm{mL}$ hexane were added, stirred for $1 \mathrm{~min}$, the flask was filled to $50 \mathrm{~mL}$ with $\mathrm{Na}_{2} \mathrm{SO}_{4} 10 \%$, vigorously stirred, and left to sit for $1 \mathrm{~h}$ in the dark. After that, the solution was transferred to amber cryogenic tubes and only a $20 \mu \mathrm{L}$ fraction of the extract was injected into a Shimadzu chromatograph to quantify the beta-carotene content (AOAC, 1995).

The statistical design used was fully randomized with split-plot arrangement and seven replicates per treatment, according to the following statistical model: $\mathrm{Y}_{\mathrm{ijk}}=\mu+\mathrm{F}_{\mathrm{i}}+\varepsilon_{\mathrm{j}}+\mathrm{T}_{\mathrm{k}}+\mathbf{F} \times \mathrm{T}_{\mathrm{k}}+\alpha_{\mathrm{ijk}}$, where $\mathrm{Y}_{\mathrm{ijk}}$ is the observation of the variable response for hay $i$ at time $k$ on replicate $j ; \mu$ is the average effect;
$\mathrm{F}_{\mathrm{i}}$ is hay effect; $\mathcal{E}_{\mathrm{j}}$ is the random error attributed to hay $i$ on replicate $j ; \mathrm{T}_{\mathrm{k}}$ is the storage time effect corresponding to $1,45,90,135,180$, and 225 days; $(\mathrm{F} \mathrm{x} \mathrm{T})_{\mathrm{ik}}$ is the effect of the interaction of hay $i \mathrm{x}$ storage time $k$; and $\alpha_{\mathrm{ijk}}$ is the random error attributed to hay $i$ at storage time $k$ on replicate $j$.

For the study of the chemical variables, Tukey's test was used $(\mathrm{P}<0.05)$ through the software $\mathrm{SAEG}^{\circledR}$ according to Ribeiro Júnior and Melo (2009). The beta-carotene concentration data showed no normality or homoscedasticity. The Kruskal-Wallis test $(\mathrm{P}<0.05)$ was applied.

\section{Results and Discussion}

No interaction $(\mathrm{P}>0.05)$ was found among the hay varieties and the storage times for all chemical parameters analyzed. However, some nutrients differed in the comparison between cultivars (Table 1).

Hay from cultivar Mineirão showed higher dry matter content $(\mathrm{P}<0.05)$ than Campo Grande, however, in this variable both hays had concentrations over $80 \%$, which, according to the National Research Council - NRC (2007), represents lower loss of cell content, with a higher proportion of the nutrient content available to the animals.

Crude protein concentrations were similar in both hays, however, they were lower than that found by Silva et al. (2009), who obtained $16.2 \%$ crude protein for Stylosanthes guianenses cv. Mineirão, and higher than the results of Ladeira et al. (2002), who found $9.4 \%$ crude protein for the same cultivar at advanced maturity stage. In the current study, the crude protein concentrations were found to be higher than the minimum amount recommended for equines in maintenance, according to the guidelines of the NRC (2007). Just the same, they were lower than the recommendation for foals, which limits its use as the only protein source in the diet of this equine category. 
Table 1. Chemical composition ( $\mathrm{g} / \mathrm{kg}$ of dry matter) of Stylosanthes hay varieties, with their respectives coefficient of variation $(\mathrm{CV})$.

\begin{tabular}{lccc}
\hline \multirow{2}{*}{ Item } & \multicolumn{2}{c}{ Varieties } & \multirow{2}{*}{ CV (\%) } \\
\cline { 2 - 3 } & Mineirão & Campo Grande & 0.45 \\
Dry matter (g/kg of fresh matter) & $900 \mathrm{a}$ & $897 \mathrm{~b}$ & 7.51 \\
Crude protein & $120 \mathrm{a}$ & $126 \mathrm{a}$ & 4.35 \\
Neutral detergent fiber & $618 \mathrm{a}$ & $601 \mathrm{~b}$ & 5.43 \\
Acid detergent fiber & $419 \mathrm{a}$ & $405 \mathrm{a}$ & 6.36 \\
Hemicellulose & $199 \mathrm{a}$ & $199 \mathrm{a}$ & 3.72 \\
Lignin $_{\text {Acid detergent insoluble nitrogen }}{ }^{1}$ & $254 \mathrm{a}$ & $233 \mathrm{~b}$ & 12.0 \\
Mineral matter & $57.0 \mathrm{a}$ & $46.1 \mathrm{~b}$ & 4.53 \\
Calcium & $89.5 \mathrm{a}$ & $83.2 \mathrm{a}$ & 5.27 \\
Phosphorus & $15.6 \mathrm{a}$ & $15.7 \mathrm{a}$ & 7.03 \\
\hline
\end{tabular}

Means with different letters within a row are different according to Tukey's test $(\mathrm{P}<0.05)$

${ }^{1}$ total nitrogen basis.

Mineirão had higher $(\mathrm{P}<0.05)$ neutral detergent fiber content than Campo Grande. Nevertheless, the values seen in this research are above those found by Silva et al. (2009), who found $47.5 \%$ of this fraction in Stylosanthes guianensis cv. Mineirão.

The acid detergent fiber fraction was similar for both hays, although the concentrations found were lower than those found by Ladeira et al. (2002) and higher than what Silva et al. (2009) described. The authors of those two studies reported $50.09 \%$ and $33.33 \%$, respectively, for Stylosanthes guianenses cv. Mineirão.

Both varieties had a similar concentration of the main cell wall component for the equine caecum and colon microbiota, since no difference $(\mathrm{P}>0.05)$ was found in the hemicellulose content of the assessed hays.

The hay from Estilosantes Campo Grande had lower $(\mathrm{P}<0.05)$ lignin concentration compared to Mineirão, which shows the good nutritional quality of this variety. According to Van Soest (1994), the close physical association between lignin and cellwall polysaccharides is the main limiting factor for microbial enzymes to access this substrate, which will reduce the digestibility of structural carbohydrates, thus reducing the forage's nutritional value.

The acid detergent insoluble nitrogen percentage was higher $(\mathrm{P}<0.05)$ in Stylosanthes guianenses cv. Mineirão hay, which, according to Van Soest (1994), means lower protein availability to the animal.

The mineral matter contents were similar $(\mathrm{P}>0.05)$ in Stylosanthes guianenses cv. Mineirão (8.95\%) and Estilosantes Campo Grande (8.32\%). However, the values found in the current study were lower than those mentioned by Vilela (2007), who found 10\% mineral matter for Stylosanthes guianenses cv. Mineirão hay produced at 60 days old. This difference can be explained by the legume's age, since both varieties studied in the current research were around 127 days old. This hypothesis matches Underwood (1999), who stated that the mineral concentrations in forages decrease as the growth stage advances due to the increase in the stem/leaf ratio.

The calcium concentration of the hay varieties studied did not differ $(\mathrm{P}>0.05)$. Nonetheless, the values of this mineral analyzed in Stylosanthes guianenses cv. Mineirão (1.56\%) and in Estilosantes Campo Grande (1.57\%) were close 
to that found by Vilela (2007) of $1.55 \%$ calcium in Mineirão. However, when the values found in the current study are compared to those mentioned by Valadares Filho et al. (2002) for lucerne hay $(1.25 \% \mathrm{Ca})$, a higher calcium concentration is seen in both varieties studied, which adds values to these forage grasses for use in equine diets since this mineral is limiting in foal diets. However, the phosphorus levels did not vary $(\mathrm{P}>0.05)$ between the two hay varieties.

In both hays, the behavior was similar along the storage period (Table 2). The storage time affected $(\mathrm{P}<0.05)$ the dry matter content of hays. This behavior had been previously described by Raymond et al. (1978), who stated that hays have a hygroscopic trait (absorbing and losing water to the environment) as a consequence of relative air humidity, which may influence the moisture content of the stored forage. Therefore, it can be inferred that the differences in dry matter content in the hays found in this research were a response to the weather conditions of the storage site over the trial period, with temperatures ranging from $13.5^{\circ} \mathrm{C}$ to $36{ }^{\circ} \mathrm{C}$ and relative air humidity between $21 \%$ and $83 \%$.

Table 2. Chemical composition (g/ kg of dry matter) of Stylosanthes guianenses cv. Mineirão and Estilosantes Campo Grande hays during storage.

\begin{tabular}{|c|c|c|c|c|c|c|c|}
\hline \multirow{2}{*}{ Item } & \multicolumn{6}{|c|}{ Time of storage (days) } & \multirow{2}{*}{ Regression $^{1}$} \\
\hline & 0 & 45 & 90 & 135 & 180 & 225 & \\
\hline $\mathrm{DM}$ & $887 \mathrm{~b}$ & $904 \mathrm{a}$ & $900 \mathrm{a}$ & $897 \mathrm{a}$ & $899 a$ & $903 \mathrm{a}$ & ns \\
\hline $\mathrm{CP}$ & $143 \mathrm{a}$ & $126 \mathrm{~b}$ & $115 \mathrm{~b}$ & $120 \mathrm{~b}$ & $115 \mathrm{~b}$ & $118 \mathrm{~b}$ & ns \\
\hline $\mathrm{NDF}$ & $586 \mathrm{a}$ & $596 \mathrm{a}$ & $622 \mathrm{a}$ & $618 \mathrm{a}$ & $631 \mathrm{a}$ & $603 \mathrm{a}$ & ns \\
\hline $\mathrm{ADF}$ & $394 \mathrm{a}$ & $395 \mathrm{a}$ & $424 \mathrm{a}$ & $418 \mathrm{a}$ & $433 \mathrm{a}$ & $409 \mathrm{a}$ & ns \\
\hline Hemicellulose & $203 \mathrm{a}$ & $201 \mathrm{a}$ & $198 \mathrm{a}$ & $200 \mathrm{a}$ & $198 \mathrm{a}$ & $193 \mathrm{a}$ & ns \\
\hline Lignin & $250 \mathrm{a}$ & $248 \mathrm{a}$ & $241 \mathrm{a}$ & $242 \mathrm{a}$ & $239 a$ & $242 \mathrm{a}$ & ns \\
\hline ADIN & $72.0 \mathrm{a}$ & $50.8 \mathrm{~b}$ & $48.3 \mathrm{~b}$ & $51.8 \mathrm{~b}$ & $41.2 \mathrm{~b}$ & $44.3 \mathrm{~b}$ & ns \\
\hline MM & $90.1 \mathrm{a}$ & $89.7 \mathrm{a}$ & $86.8 \mathrm{a}$ & $84.3 \mathrm{a}$ & $83.4 \mathrm{a}$ & $84.0 \mathrm{a}$ & ns \\
\hline $\mathrm{Ca}$ & $17.4 \mathrm{a}$ & $15.2 \mathrm{~b}$ & $15.4 \mathrm{~b}$ & $15.4 \mathrm{~b}$ & $15.2 \mathrm{~b}$ & $15.4 \mathrm{~b}$ & ns \\
\hline $\mathrm{P}$ & $2.9 \mathrm{a}$ & $2.7 \mathrm{a}$ & $2.6 \mathrm{a}$ & $2.6 \mathrm{a}$ & $2.6 \mathrm{a}$ & $2.7 \mathrm{a}$ & ns \\
\hline
\end{tabular}

Means with different letters within a row are different according to Tukey's test $(\mathrm{P}<0.05)$; ${ }^{1}$ Non-significant regression (ns); $\mathrm{CP}$ : crude protein; NDF: neutral detergent fiber; ADF: acid detergent fiber; ADIN: acid detergent insoluble nitrogen (total nitrogen basis); MM: mineral matter; Ca: calcium; P: phosphorus.

The crude protein concentration was higher $(\mathrm{P}<0.05)$ on the first day of storage when compared to the other assessments. The crude protein behavior during hay storage was similar to that found by Nascimento et al. (2000), who noticed a decrease of this nutrient in the first 30 days of storage.

The neutral detergent fiber, acid detergent fiber, hemicellulose, and lignin contents did not vary $(\mathrm{P}>0.05)$ over the 225 days of storage, suggesting the haymaking process was properly carried out.
According to the NRC (2007), the fiber components of the forage grass must remain unaltered over hay storage.

The hemicellulose fraction did not vary $(\mathrm{P}>0.05)$ over the storage period. The acid detergent insoluble nitrogen levels varied $(\mathrm{P}<0.05)$ during storage, being similar to those found by Coblentz et al. (2000), who also reported high concentrations of the acid detergent insoluble nitrogen fraction on the first days of storage for lucerne hays. Those authors 
considered this period the most critical in the forage quality degradation. Buckmaster et al. (1989) explained that acid detergent insoluble nitrogen formation is directly linked to the increase in temperature that takes place due to microorganism activity on the first days of storage, which favors the binding of the protein to the indigestible portion of the fiber.

The storage time did not influence $(\mathrm{P}>0.05)$ the mineral matter content of hays, matching the NRC (2007), which pointed out that hays maintain a stable mineral content over storage.

However, the hays showed differences $(\mathrm{P}<0.05)$ in the calcium content over time, since the highest concentration of this mineral was detected in the beginning of the storage period, indicating that the calcium concentration must be assessed in the diets of foals fed with stored hays given how important this mineral is to their bone development.

The comparison of the hay varieties showed no difference $(\mathrm{P}>0.05)$ in the beta-carotene concentrations (Table 3), which can be explained by the fact that both cultivars belong to the same genus (Stylosanthes). Park et al. (1983) noticed differences of up to $50 \%$ in the beta-carotene storage capacity of different forage species (Bromus inermis, Phalaris arundinacea, Agropyron repens).

Table 3. Beta-carotene concentration ( $\mathrm{mg} / \mathrm{kg} \mathrm{DM})$ in hay.

\begin{tabular}{ccccccc}
\hline \multirow{2}{*}{ Varieties } & \multicolumn{7}{c}{ Time of storage (days) } \\
\cline { 2 - 6 } & 0 & 45 & 90 & 135 & 180 & 225 \\
\hline Mineirão & $1,083.6$ & 461.13 & 364.16 & 430.20 & 288.18 & 258.34 \\
Campo Grande & 660.20 & 404.26 & 318.92 & 324.03 & 287.24 & 242.51 \\
\hline
\end{tabular}

Similar medians for Kruskall-Wallis test $(\mathrm{P}>0.05)$.

The storage period did not change $(\mathrm{P}>0.05)$ the beta-carotene concentration of hays. Although a numerical discrepancy is observed in the concentration of beta-carotene of the stored hay, the nature of the response evaluated prevented a statistical analysis that corroborates the difference observed numerically. Similar results were found by Bruhn and Oliver (1978) for lucerne hays produced with $89.2 \%$ dry matter and stored for 126 days. Those authors found a decrease $(\mathrm{P}<0.01)$ in the beta-carotene concentration of hays produced with 91\% dry matter and highlighted the importance of this variable in the conservation of pro-vitamin A. In the current research, both varieties studied showed dry matter content below 91\% (Table 1), which contributes to beta-carotene conservation.

The storage period has little impact on the nutritional quality of the assessed hays. The
Stylosanthes guianensis cv. Mineirão and, mainly, Estilosantes Campo Grande hay varieties have potential to be used in equine diets.

\section{References}

ASSOCIATION OF OFFICIAL ANALYTICAL CHEMISTRY - AOAC. Official Methods of Analysis. Arlington: AOAC International, 1995. 1025 p.

BRUHN, J. C.; OLIVER, J. C. Effect of storage on tocopherol and carotene concentrations in alfafa hay. Journal of Dairy Science, Champaign, v. 61, n. 7, p. 980982, 1978.

BUCKMASTER, D. R.; ROTZ, C. A.; MERTENS, D. R. A model of alfalfa hay storage. Transactions Association of Agricultural and Bilogical Engineers, Michigan, v. 32, n. 1, p. 30-36, 1989.

CARVAlHO, R. T. L.; HADDAD, C. M. Pastagens e alimentação de equinos. Piracicaba: FEALQ, 1987. 85 p. 
COBLENTZ, W. K.; TURNER, E. J.; SCARBROUGH, D. A.; LESMEISTER, K. E.; JOHNSON, Z. B.; KELlOGG, D. W.; COFFEY, K. P.; MCBETH, L. J.; WEYERS, J. S. Storage characteristics and nutritive value changes in bermudagrass hay as affected by moisture content and density of rectangular bales. Crop Science, Madison, v. 40, n. 5, p. 1375-1383, 2000.

JERBA, V. F.; FERNANDES, C. D.; POTT, A. Relação entre número de estegmata na epiderme foliar e intensidade da antracnose em Stylosanthes spp. Pesquisa Agropecuária Brasileira, Brasília, v. 41, n. 1, p. 175-178, 2006.

LADEIRA, M. M.; RODRIGUEZ, N. M.; BORGES, I. Balanço de nitrogênio, degradabilidade de aminoácidos e concentração de ácidos graxos voláteis no rúmen de ovinos alimentados com feno de Stylosanthes guianensis. Revista Brasileira de Zootecnia, Viçosa, MG, v. 1, n. 6, p. 2357-2363, 2002.

NASCIMENTO, J. M.; COSTA, C.; SILVEIRA, A. C.; ARRIGONI, M. B. Influência do método de fenação e tempo de armazenamento sobre a composição bromatológica e ocorrência de fungos no feno de alfafa (Medicago sativa, L. cv. Flórida 77). Revista Brasileira de Zootecnia, Viçosa, MG, v. 29, n. 3, p. 669-677, 2000.

NATIONAL RESEARCH COUNCIL - NRC. Nutrient requirements of horses. Washington: National Academy Press, 2007. $341 \mathrm{p}$.

PARK, Y. W.; ANDERSON, M. J.; WALTERS, J. L.; MAHONEY, A. W. Effects of processing methods and agronomic variables on carotene contents in forages and predicting carotene in alfalfa hay with Near-infraredreflectance Spectroscopy. Journal of Dairy Science, Champaign, v. 66, n. 2, p. 235-245, 1983.

RAYMOND, F.; SHEPPERSON, G.; WALTHAM, R. Forage conservation and feeding. Sulfolk: Farming Press, 1978. 208 p.
REIS, R. A. Técnicas para produção e conservação de fenos de forrageiras de alta qualidade. In: SIMPÓSIO SOBRE PRODUÇÃO E UTILIZAÇÃO DE FORRAGENS CONSERVADAS, 1., 2001. Maringá. Anais... Maringá: UEM, 2001. p. 1-39.

RIBEIRO JÚNIOR, J. I.; MELO, A. L. P. Guia prático para utilização do SAEG. Viçosa, MG: Folha Artes Gráficas Ltda., 2009. 288 p.

SILVA, D. J.; QUEIROZ, A. C. Análise de alimentos: métodos químicos e biológicos. Viçosa, MG: Imprensa Universitária, 2002. 235 p.

SILVA, V. P. L.; ALMEIDA, F. Q.; MORGADO, E. S.; FRANÇA, A. B.; VENTURA, H. T.; RODRIGUES, L. M. Digestibilidade dos nutrientes de alimentos volumosos determinada pela técnica dos sacos móveis em equinos. Revista Brasileira de Zootecnia, Viçosa, MG, v. 38, n. 1, p. 82-89, 2009.

UNDERWOOD, E. J. The mineral nutrition of livestock. New York: CABI Publishing, 1999. 624 p.

VALADARES FILHO, S. C.; ROCHA JÚNIOR, V. R.; CAPPELLE, E. Z. Tabelas brasileiras de composição de alimentos para bovinos. Viçosa, MG: Imprensa Universitária, 2002. 297 p.

VAN SOEST, P. J. Nutritional ecology of the ruminant. Ithaca: Cornell University Press, 1994. 476 p.

VAN SOEST, P. J.; ROBERTSON, J. B.; LEWIS, B. A. Methods for dietary fiber, neutral detergent fiber and nonstarch polysaccharides in relation to animal nutrition. Journal of Dairy Science, Champaign, v. 74, n. 10, p. 3583-3597, 1991.

VILELA, H. Série leguminosas tropicais - gênero Stylozanthes (Stylozanthes guianensis) Stilozanthes guianensis. Belo Horizonte: Portal Agronomia, 2007. Disponível em: <http://www.agronomia.com. br/conteudo/artigos/artigos_leguminosas_tropicais stylozant es_guianensis.htm>. Acesso em: 22 out 2012. 
